DOI: $10.18778 / 2084-140 X .10 .27$

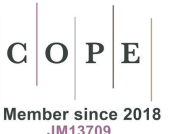

JM13709

\title{
A Companion to the Byzantine Culture of War, ca. 300-1204, ed. YANNIS STOURAITIS, Brill, Leiden-Boston 2018 [= Brill's Companions to the Byzantine World, 3], 6 maps, 3 figures, index, pp. X, 490.
}

$\mathrm{T}$ he presented volume is edited by Yannis Stouraitis, a lecturer of Byzantine history at the University of Edinburgh, whose research interests lie in the social and cultural history of the Byzantine Empire from $6^{\text {th }}$ to $13^{\text {th }}$ century, especially focusing on the issues of Byzantine war ideology, identity and migration in the medieval Eastern Mediterranean ${ }^{1}$. The volume is divided in two parts, six chapters each, and preceded by an Introduction by Y. Stouraitis, who argues that the changes taking place in Byzantine warfare from Late Antiquity to ca. 1204 should be understood on a macro-structural scale (and provides the examples of the impact of the Germanic migrations of the $5^{\text {th }}$ century; the Arab-Muslim expansion since the $7^{\text {th }}$ century and $11^{\text {th }}$ century Seljuk invasion) as a part of the phenomena of penetration and destabilization of the Byzantine's political, social and cultural structures (p. 1-19). However, this is not a classic introduction to the presented topic, but actually a separate article.

Part 1 entitled The Mentality of War is opened by Paul Stephenson's chapter on the issue of the Byzantine theology of victory (p. 23-58).

\footnotetext{
${ }^{1}$ Cf. Y. Stouraitis, Krieg und Frieden in der politischen und ideologischen Wahrnehmung in Byzanz (7.-11. Jahrhundert), Wien 2009 [= BG.E, 5]; Byzantine War Ideology between Roman Imperial Concept and Christian Religion. Akten des Internationalen Symposiums (Vienna, 19-21 Mai 2011), ed. J. Koder, Y. Stouraitis, Wien 2012 [= VB, 30]; Migration Histories of the Medieval Afroeurasian Transition Zone. Aspects of Mobility between Africa, Asia and Europe, 300-1500 C.E., ed. J. Preiser-Kapeller, L. ReinFANDT, Y. STOURAITIS, Boston-Leiden 2020 [= SGSH, 39; SGMH, 13].
}

The author discusses the significance of two symbols: the True Cross (which indicated that outcomes of all battles were intended by God), and the Virgin, Theotokos (as the one who, through its icons and relics, can provide divine protection to the emperors, e.g. by summoning holy warriors, as Sts. Theodore or George for an aid) for the Byzantine ideology of war. In the next chapter, Y. Stouraitis analyzes the shaping of the Byzantine war ethic and popular attitudes towards warfare in the Byzantine historiography (p. 59-91). The author points to such ideas as Roman/Byzantine Reconquista, Just War or Heraclius' concept of sacralization of defence, claiming that the Christian symbols played an important role in the symbolic legitimization of warfare. Y. Stouraitis' second chapter in the volume discusses the phenomenon of civil wars within the Byzantine Empire that was torn apart by provincialism and separatism between the $4^{\text {th }}$ and the $12^{\text {th }}$ centuries (p. 92-123). He sees a change in the role played by internal conflicts which, after the fall of the Comnenians at the end of the $12^{\text {th }}$ century, transformed: initially, they were important for the reproduction of the imperial system but as time passed by, they became a factor that completely disintegrated and destroyed the Empire. Michael Grünbart's chapter considers the images of the Byzantine's enemies based on the romanitas/barbaricum dichotomy (p. 124-159). The author uses both pictorial and written sources, showing a long Roman and Byzantine tradition of distinguishing the foreigners from the 'civilized' Empire's citizens, e.g. through the imperial propaganda of victory 
and displaying the 'other'. Stamatina McGrath studies the role of battle narratives in the Byzantine historiography as a relay of the values of the warrior culture and, at the same time, a Christian society, transmitting the right pattern of behaviour to the collective memory (p. 160-195). Tilemachos Lounghis considers the political ideas of resolving conflicts in the Byzantine Empire, focusing on four main issues: (1) avoiding war; (2) avoiding pressure from the East and West; (3) avoiding aggressive wars; and (4) Byzantine diplomacy towards the Crusaders (p. 196-226). He claims that the Byzantine Empire, protecting its interests by various alternative means, only rarely and very reluctantly avoided armed solutions.

Part 2 is entitled Warfare as Socio-Political Praxis. It is opened with a chapter by Savvas Kyriakidis about the transformation of the Byzantine army structure from the rule of Constantine the Great until 1204, in which he shows la longue durée of the military structures of the Roman Empire (p. 229-258). Denis Sullivan presents the Byzantine strategies used in the imperial diplomacy and its ideological background that lies in the idea of Roman world supremacy (p. 259-307). The author describes the political and military history of the wars on the Byzantine frontiers in Asia and Europe up to the Fourth Crusade. Salvatore Cosentino analyzes the Byzantine naval warfare focusing on the administrative, economic and military issues (p. 308-355). He presents the arguments for Byzantine thalassocracy that begun ca. $10^{\text {th }}$ century and lasted until at least the $12^{\text {th }}$ century Christos G. Makrypoulias considers the Byzantine siege warfare as an art of defence (p. 356-393). He uses the concept of 're-capture', arguing that the protection of Byzantine territories relied on the strategy of elastic defence; a city or a stronghold captured by the enemy had to be recaptured to maintain the integrity of the frontiers' defensive network. Therefore, a siege was a part of defensive strategy, even in the offensive campaigns. Philip Rance's chapter is about the social status and political role of the Byzantine soldiers (p. 394-439). The author discusses such issues as recruitment, payments and privileges received, as well as the socio-economic status of the soldiers, their policing role or their relations with civilians. He also elaborates on their role in church and imperial politics, e.g. as an important factor in attempts to gain/hold the throne. In the final chapter of the volume, Georgios Theotokis studies the Byzantine arms and armour based on the written, pictoral and material sources, showing a multitude of terms appearing in the Greek sources describing weapons, as well as the variety of equipment used in the Empire (p. 440-472).

The presented volume seems to be an apt and multifaceted introduction to Byzantine warfare from the $4^{\text {th }}$ to the $13^{\text {th }}$ century, and its findings are accessible both to specialists in the field as well as to novice scholars. However, it should be emphasized that the scientific achievements of scholars writing in the Slavic languages were taken into account to an almost negligible degree, and the choice of secondary literature, apart from English, but e.g. in French, appears to be selective.

\section{BIBLIOGRAPHY}

Byzantine War Ideology between Roman Imperial Concept and Christian Religion. Akten des Internationalen Symposiums (Vienna, 19-21 Mai 2011), ed. J. KodeR, Y. STOURAitis, Wien 2012 [= Veröffentlichungen zur Byzanzforschung, 30].

Migration Histories of the Medieval Afroeurasian Transition Zone. Aspects of Mobility between Africa, Asia and Europe, 300-1500 C.E., ed. J. Preiser-KapelLer, L. Reinfandt, Y. Stouraitis, Boston-Leiden 2020 [= Studies in Global Social History, 39; Studies in Global Migration History, 13].

Stouraitis Y., Krieg und Frieden in der politischen und ideologischen Wahrnehmung in Byzanz (7.-11. Jahrhundert), Wien 2009 [= Byzantinische Geschichtsschreiber. Ergänzungsband, 5].

Tomasz Pełech (Wrocław/Clermont-Ferrand)* iD https://orcid.org/0000-0002-3722-568X

${ }^{*}$ University of Wrocław/Université Clermont-Auvergne 